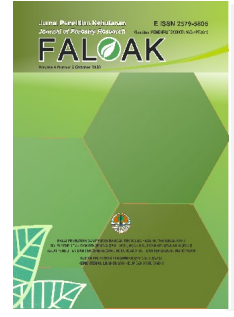

Jurnal Penelitian Kehutanan Faloak (2021) 5(2), 74-89

\title{
JURNAL PENELITIAN KEHUTANAN FALOAK
}

Akreditasi KEMENRISTEKDIKTI: 10/E/KPT/2019

http://ejournal.forda-mof.org/ejournal-litbang/index.php/JPKF

\section{KERAGAMAN DAN POTENSI JAMUR DI HUTAN KOTA SEMARANG, JAWA TENGAH \\ (Diversity and Potency of Macrofungi at City Forest \\ Of Semarang, Central Java)}

\section{Ferry Augustinus ${ }^{1}$ dan Ivan Permana Putra ${ }^{2 *}$}

${ }^{1}$ Komunitas Pemburu Jamur Indonesia, Semarang, Jawa Tengah

${ }^{2}$ Divisi Mikologi, Departemen Biologi, Institut Pertanian Bogor, Jalan Agatis, Kampus IPB, Darmaga, Jawa Barat

\begin{abstract}
Macrofungi are the organism which often overlooked in the recording effort of biodiversity in Indonesia. Until nowdays, the data on mushroom diversity in Indonesia is still limited. In fact, they have various benefits and are easily found in various ecological niches in Indonesia. However, the forest ecosystem around urban residential areas is a place that rarely records the mushroom diversity and its potential uses. This study aimed to provide preliminary information regarding some macrofungi's diversity and potential use in the urban forest, Gunungpati Subdistrict, Semarang City, Central Java. A total of ten fungi were identified and described in this study. All these fungi are part of the phylum of Basidiomycota, which is divided into six orders and nine families. They are: Auricularia cf. nigricans, Tremella cf. fuciformis, Gymnopus sp., Coprinellus sect. domestici, Macrocybe sp., Lycoperdon cf. curtisii, Ganoderma sp., Lentinus cf. sajor-caju, Mutinus cf. elegans, and Geastrum sp. Some mushrooms are known to have potential as food (Auricularia cf. nigricans, Coprinellus sect. Domestici, Macrocybe sp., Lycoperdon cf. curtisii, and Lentinus cf. sajor-caju) and medicine (Auricularia cf. nigricans, Ganoderma sp. and Tremella cf. fuciformis). This study is the first to document the diversity of fungus in the research area. It is expected to be used to disseminate mycology by a variety of interested parties.
\end{abstract}

Keywords: City Forest, Macrofungi, Potency, Diversity, Indonesia

\begin{abstract}
ABSTRAK
Jamur merupakan organisme yang sering terabaikan pada saat pencatatan keragaman hayati di Indonesia. Hingga saat ini, data mengenai diversitas jamur di Indonesia masih sangat rendah. Padahal, organisme ini memilki berbagai manfaat dan mudah ditemukan pada berbagai relung ekologi di Indonesia. Kawasan hutan di sekitar pemukiman perkotaan merupakan tempat yang jarang memiliki catatan keragaman dan potensi pemanfaatan jamur. Penelitian ini bertujuan untuk menyediakan informasi awal mengenai keragaman jamur di di Kecamatan Gunungpati, Kota Semarang, Jawa Tengah. Sebanyak10 jamur berhasil diidentifikasi dan dipertelakan pada penelitian ini. Seluruh jamur tersebut merupakan bagian dari filum Basidiomycota yang terbagi ke dalam 6 ordo dan 9 famili. Jamurjamur tersebut adalah: Auricularia cf. nigricans, Tremella cf. fuciformis, Gymnopus sp., Coprinellus sect. Domestici, Macrocybe sp., Lycoperdon cf. curtisii, Ganoderma sp., Lentinus cf. sajor-caju, Mutinus cf. elegans, dan Geastrum sp. Beberapa jamur diketahui memiliki potensi sebagai bahan pangan (Auricularia cf. nigricans, Coprinellus sect. Domestici, Macrocybe sp., Lycoperdon cf. curtisii, dan Lentinus cf. sajor-caju) dan obat (Auricularia cf. nigricans, Ganoderma sp. dan Tremella cf. fuciformis). Tulisan ini merupakan catatan pertama mengenai keragaman jamur di lokasi penelitian dan diharapkan mampu untuk dijadikan sebagai bahan diseminasi ilmu mikologi oleh berbagai pihak terkait.
\end{abstract}

Kata kunci : Hutan Kota, Jamur, Manfaat, Ragam, Indonesia

\begin{tabular}{|c|c|}
\hline Article & \\
\hline Corresponding Author & : ivanpermanaputra@apps.ipb.ac.id (Ivan Permana Putra) \\
\hline Articel History & $\begin{array}{l}\text { : Received } 29 \text { July 2021; received in revised from } 3 \text { September 2021; accepted } 14 \text { September 2021; } \\
\text { Available online since } 31 \text { October } 2021\end{array}$ \\
\hline How to cite this article & Agustinus, Ferry., Putra, Ivan Permana (2021). Keragaman dan potensi jamur di hutan Kota Semarang, \\
\hline & $\begin{array}{lccccccc}\text { Jawa } & \text { Tengah. Jurnal Penelitian } & \text { Kehutanan } & \text { Faloak, } & \text { 5(2):74-89. } & \text { DOI } & \text { : } \\
\text { http://doi.org/10.20886/jpkf.2021.5.2.74-89 } & & & & \end{array}$ \\
\hline
\end{tabular}

Read Online 


\section{PENDAHULUAN}

Jamur merupakan fungi makroskopik yang tubuh buahnya dapat dilihat dengan mata telanjang tanpa bantuan mikroskop (Arora, 1986). Jamur merupakan organisme heterotrof dan merupakan pendekomposer handal, sehingga merupakan bagian penting dalam sebuah ekosistem. Anggotanya meliputi sebagian besar Basidiomycota dan sedikit Ascomycota (Mueller et al., 2007). Hingga saat ini, informasi mengenai keragaman jamur di Indonesia masih rendah. LIPI (2019) menyatakan bahwa hingga tahun 2017 baru tercatat sebanyak 2273 jenis fungi (makro dan mikroskopik) di Indonesia, atau hanya sekitar $0.15 \%$ dari total estimasi yang ada di seluruh dunia.

Jamur merupakan organisme yang menarik tetapi kurang banyak diteliti dan dimanfaatkan di Indonesia. Kelompok organisme ini sangat mudah dijumpai di berbagai kondisi lingkungan. Sifatnya yang kosmopolitan, memungkinkan jamur mudah ditemukan pada berbagai macam tipe habitat, mulai dari kawasan hutan alami (Putra et al., 2017; 2019), hutan wisata (Putra et al., 2018), hingga di sekitar pemukiman penduduk (Putra \& Astuti, 2021). Selain itu, informasi tentang potensi jamur liar di daerah hutan perkotaan masih sangat sedikit dikaji. Laporan mengenai keragaman dan potensi jamur di kawasan padat penduduk sangat jarang dilaporkan di Indonesia (Putra \& Astuti, 2021). Upaya inventarisasi ragam dan potensi jamur dari berbagai lokasi terutama wilayah yang belum memiliki catatan khusus mengenai hal tersebut sangat penting untuk dilakukan.

Daerah Gunungpati merupakan salah satu kecamatan di Kota Semarang dengan udara yang relatif sejuk dan topografi berbukit-bukit dengan ketinggian 295 mdpl dan curah hujan $1853 \mathrm{~mm} / \mathrm{bulan}$ (https://kecgunungpati. semarangkota.go.id/profil-kecamatan). Kondisi tersebut merupakan lingkungan yang cocok untuk pertumbuhan jamur. Keragaman dan potensi jamur di daerah ini juga masih belum dideskripsikan secara ilmiah. Terlebih lagi, laju perubahan fungsi lahan hijau menjadi perumahan yang tinggi (Dewi \& Rudirto, 2013), dan mengakibatkan hilangnya habitat jamur. Hal ini menimbulkan kekhawatiran bahwa banyak jamur potensial yang akan hilang sebelum sempat dideskripsikan ataupun dimanfaatkan oleh penduduk Semarang. Tujuan dari penelitian ini adalah menyediakan informasi awal tentang keragaman jamur di Kecamatan Gunungpati sehingga dapat menjadi referensi untuk menggali potensi jamur di masa mendatang.

\section{METODE PENELITIAN}

Penelitian ini dilakukan dari bulan Februari 2020 sampai dengan Juni 2021. Suhu udara saat penelitian berkisar $20^{\circ} \mathrm{C}-33^{\circ} \mathrm{C}$. Penelitian dilakukan dengan menjelajahi sebagian besar zona hijau yang merupakan kawasan hutan kota di Kecamatan Gunungpati, Semarang (Gambar 1) melalui jalan setapak dan jalan raya yang membelah 16 Kelurahan. Eksplorasi jamur dilakukan dengan opportunistic sampling method mengikuti deskripsi dari Prayudi et al. (2019). Sampel yang ditemukan kemudian dipertelakan mengikuti penjelasan Putra et al. (2018) dan Putra (2021). Parameter makroskopik yang diobservasi meliputi cara tumbuh, bentuk tubuh buah, perubahan kebasahan, warna tudung (cap) 


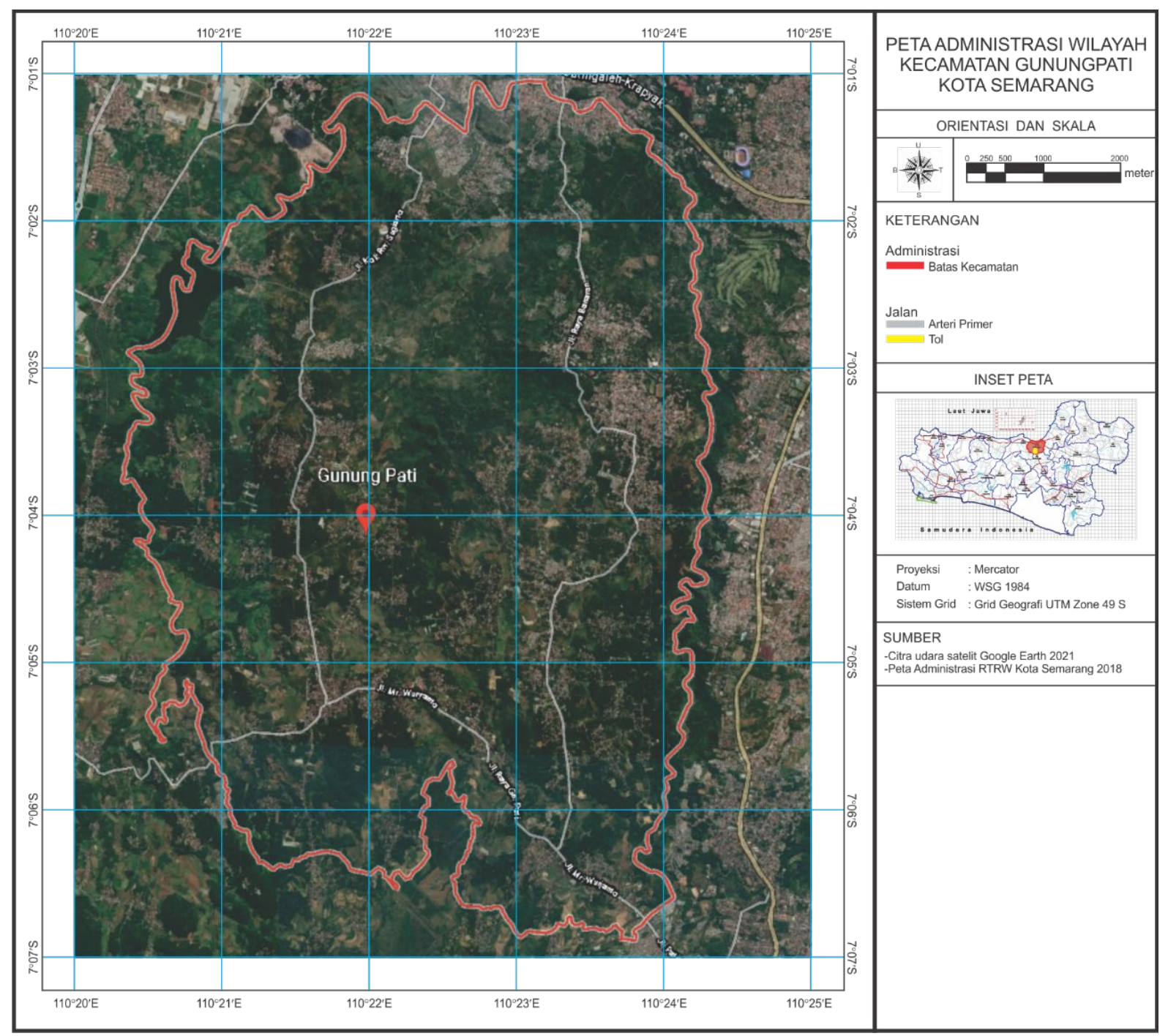

\section{Gambar 1. Lokasi Penelitian Hutan Kota Kecamatan Gunungpati Figure 1. Research site Urban Forest Gunungpati Subdistrict}

ketika tubuh buah muda dan tua, diameter cap, bentuk atas dan bawah pada cap, permukaan cap, tepian cap, margin cap, tingkat kebasahan, tipe himenofor (lamela, pori, gerigi) meliputi: cara menempel pada stipe, panjang, jarak antar baris, dan margin. Karakter lain yang diobservasi adalah bentuk stipe, warna stipe (ketika muda dan tua), permukaan stipe, posisi penempelan pada cap, tipe penempelan stipe pada substrat, penampang stipe, partial veil dan universal veil, tekstur tubuh buah, bau, rasa serta informasi penggunaannya sebagai bahan pangan (edible atau non edible) melalui studi literatur dan wawancara kepada masyarakat untuk mendapatkan informasi mengenai pemanfaatan jamur yang ditemukan. Deskripsi jamur kemudian dijadikan sebagai acuan saat identifikasi. Identitas taksonomi diobservasi hingga ke tingkat genus dan spesies dengan menggunakan beberapa acuan identifikasi diantaranya Arora (1986), Rokuya et al. (2011), Desjardin et al. (2015), dan Putra \& Hafazallah (2020). Pemberian nama hingga ke level spesies diberikan penanda cf. (confer) yang merujuk 
kepada karakter terdekat jamur yang diidentifikasi pada identitas taksonomi tertentu dan mengikuti aturan indexfungorum.

\section{HASIL DAN PEMBAHASAN}

Sebanyak 10 spesies jamur, yang terdiri dari 6 ordo dan 9 famili berhasil diidentifikasi dan dipertelakan pada penelitian ini (Tabel 1). Spesies-spesies jamur tersebut adalah: Auricularia cf. nigricans, Tremella cf. fuciformis, Gymnopus sp., Coprinellus sect. Domestici, Macrocybe sp., Lycoperdon cf. curtisii, Ganoderma sp., Lentinus cf. sajor-caju, Mutinus cf. elegans, dan Geastrum sp.

Tabel 1. Posisi taksonomi jamur pada penelitian ini

Table 1. The taxonomical position of macrofungi in this study

\begin{tabular}{|c|c|c|c|c|}
\hline $\begin{array}{l}\text { Filum } \\
\text { (Phyllum) }\end{array}$ & $\begin{array}{l}\text { Kelas } \\
\text { (Class) }\end{array}$ & $\begin{array}{l}\text { Ordo } \\
(\text { Ordo })\end{array}$ & $\begin{array}{l}\text { Famili } \\
\text { (Family) }\end{array}$ & $\begin{array}{l}\text { Spesies } \\
\text { (Species) }\end{array}$ \\
\hline \multirow{10}{*}{ Basidiomycota } & Agaricomycetes & Auriculariales & Auriculariaceae & Auricularia cf.nigricans \\
\hline & & Agaricales & Omphalotaceae & Gymnopus sp. \\
\hline & & & Psathyrellaceae & Coprinellus sect. Domestici \\
\hline & & & Callistosporiaceae & Macrocybe sp. \\
\hline & & & Lycoperdaceae & Lycoperdon cf. curtisii \\
\hline & & Polyporales & Polyporaceae & Ganoderma sp. \\
\hline & & & & Lentinus cf. sajor-caju \\
\hline & & Phallales & Phallaceae & Mutinus cf.elegans \\
\hline & & Geastrales & Geastraceae & Geastrum sp. \\
\hline & Tremellomycetes & Tremellales & Tremellaceae & Tremella cf. fuciformis \\
\hline
\end{tabular}

Jamur yang dijumpai dalam penelitian ini seluruhnya dari filum Basidiomycota karena jamur kelompok ini mudah dijumpai dan jenisnya tergolong sangat banyak. Semua jamur yang ditemukan pada penelitian ini memiliki fungsi sebagai dekomposer di ekosistem. Beberapa jamur pada penelitian ini merupakan jamur liar edible seperti: Auricularia cf. nigricans, Coprinellus sect. Domestici, Macrocybe sp., Lycoperdon cf. curtisii, Lentinus cf. sajor-caju danTremella cf. fuciformis. Selain itu, beberapa jamur yang lainnya memiliki potensi sebagai bahan obat antara lain: Auricularia cf. nigricans, Ganoderma sp. dan Tremella cf. fuciformis. Menurut Li et al. (2021), terdapat sekitar 2000 jenis jamur liar yang dapat dimakan dari total 1,5 juta estimasi jamur yang ada di seluruh dunia. Selain dikonsumsi sebagai bahan pangan, jamur liar juga banyak dimanfaatkan sebagai obat (Gregori \& Pohleven, 2014; Badalyan, 2020).

Jamur dari ordo Agaricales merupakan kelompok paling banyak dijumpai dalam penelitian ini. Empat famili jamur yang dijumpai adalah Omphalotaceae, Psathyrellaceae, Callistosporiaceae, dan Lycoperdaceae. Tampubolon et al. (2013) melaporkan bahwa Agaricales merupakan ordo yang memiliki persebaran yang paling banyak dibandingkan ordo lainnya di alam. Menurut Putra (2021), sebagian besar laporan keragaman jamur di Indonesia tidak dilengkapi dengan pertelaan dari jamur yang dilaporkan sehingga menyulitkan masyarakat untuk mempelajarinya. Berikut adalah deskripsi dan karakteristik jamur-jamur yang ditemukan di daerah Gunungpati pada penelitian ini. 


\section{Auricula cf. nigricans}

Tubuh buah tumbuh bergerombol (gregarious) pada dahan pohon mati, saat muda tubuh buah berbentuk seperti cawan (cup shaped) atau telinga (ear shaped) (Gambar 2a), tidak bertangkai (sessile), tekstur kenyal, basah, hingga seperti gelatinous (jelly-like). Bagian dalam telinga/cawan berwarna hitam mengkilat, bagian luar berambut halus (velvet like) berwarna kecoklatan (brownish) (Gambar 2a-b). Diameter cawan 4-5 cm, dengan ketebalan 1-2 $\mathrm{mm}$. Semakin dewasa bentuk cawan/telinga, tubuh buah jamur makin berkerut-kerut.
Auricularia secara umum dapat dimakan (edible) dan memiliki banyak manfaat medis (Bandara et al., 2019; Mapoung et al., 2021). Masyarakat sekitar lokasi penelitian menyebut jamur ini sebagai jamur kuping. Umumnya warga yang tinggal di daerah perkotaaan jarang memanfaatkan jamur Auricularia yang tumbuh liar walaupun banyak dijumpai (Putra \& Hafazallah 2020). Hal ini kemungkinan dikarenakan ketidaktahuan dan kurangnya diseminasi informasi jamur pangan liar di wilayah tersebut.

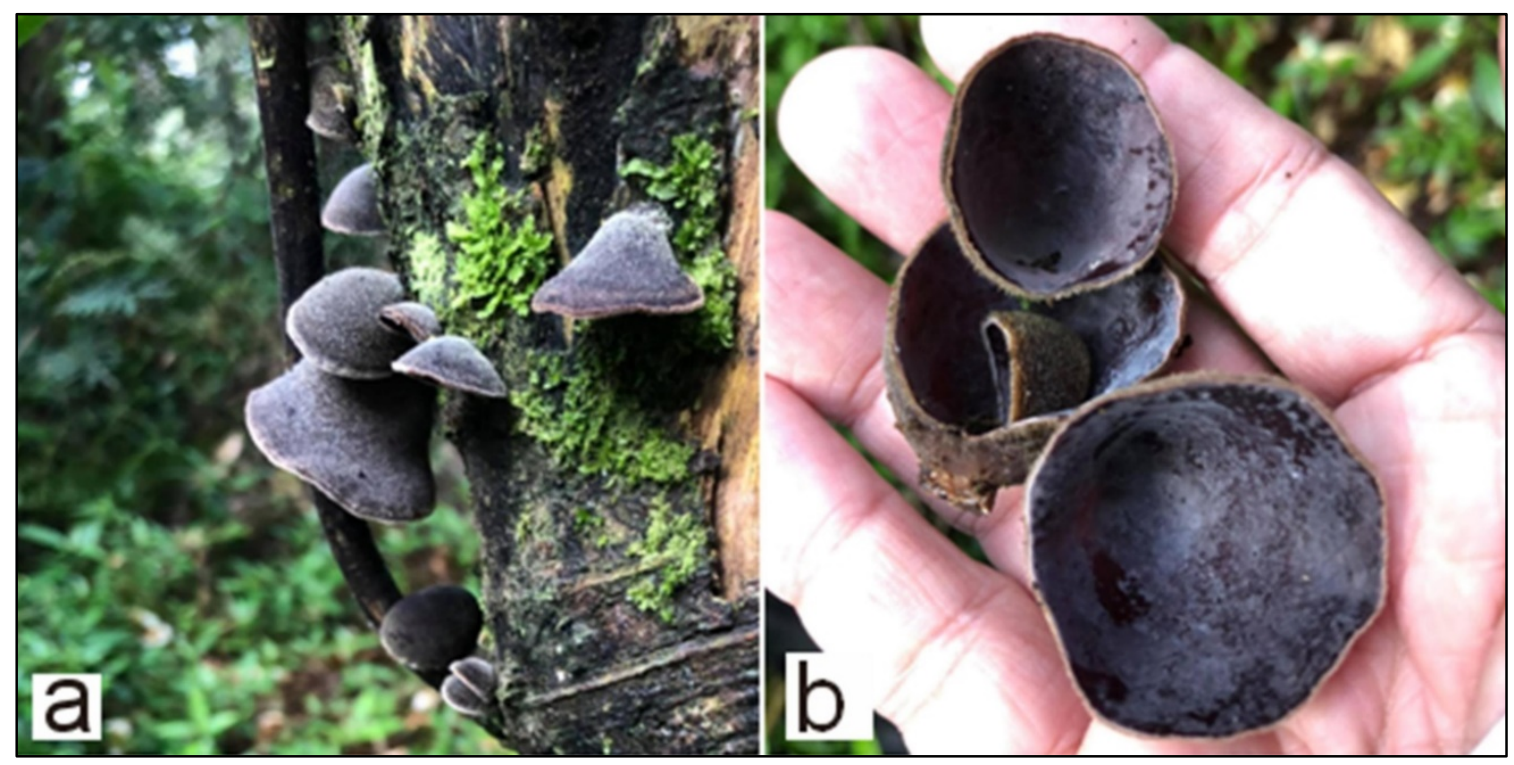

Gambar 2. Karakteristik makroskopik Auricularia cf. nigricans. a) Tubuh buah tampak atas. b) Tubuh buah tampak bawah.

Figure 2. The macroscopic characteristics of Auricularia cf.nigricans. a) The upperside of basidiomata. b) the underside of basidiomata. 


\section{Tremella cf. fuciformis}

Tubuh buah tumbuh menempel erat tanpa tangkai pada pohon mati, basidioma berwarna putih semi transparan, dan bertekstur kenyal (jelly-like) (Gambar 3b). Pada awal pertumbuhan, massa primordia berada dalam satu titik (diameter 2-5 cm) yang kemudian perlahan meluas dari titik tersebut $(10-15 \mathrm{~cm})$ (Gambar 3c), berbentuk lembaran kenyal tipis berlobus, terlihat keriting dari kejauhan. Pada titik tumbuhnya terlihat warna kuning yang merupakan fungi inangnya yakni, Hypoxylon (Gambar 3a). Kedua jamur ini diduga bersimbiosis (Kuo, 2008). Jamur ini dapat dimakan (edible) dan bermanfaat medis dan kosmetik (Shahrajabian et al., 2020). Hasil wawancara dengan masyarakat sekitar menunjukkan bahwa jamur ini belum dimanfaatkan bahkan tidak memiliki nama lokal.

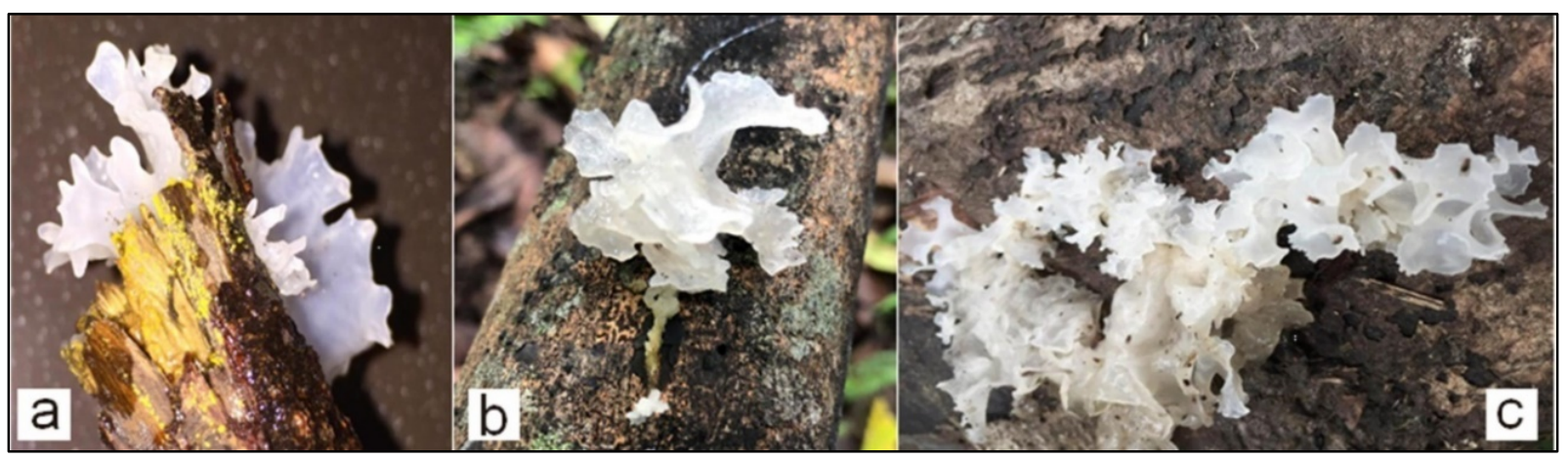

Gambar 3. Karakteristik makroskopik Tremella cf. fusiformis. a) Tubuh buah (putih) dan inangnya (kuning). b) Tubuh buah muda. c) Tubuh buah dewasa.

Figure 3. The macroscopic characteristics of Tremella cf. fusiformis. a) Basidiomata (white) and the host (yellow). b) Young basidiomata. c) Mature basidiomata.

\section{Gymnopus sp.}

Basidioma tumbuh di sekitar perakaran bambu. Pileus berbentuk bulat seperti lonceng (bell-shaped) saat muda dan menjadi cembung (convex) hingga datar (plane) saat dewasa. Tudung memiliki tonjolan (central umbo) yang mendominasi, tepian berstriata (striate), berwarna coklat tua pada bagian umbo dan tepian berwarna coklat lebih muda (Gambar 4a-b). Saat tua, warna tudung menjadi lebih terang/krem. Himenofor berlamela (Gambar 4c), tipe pelekatan adnexed, berwarna keputihan- krem, bilah lamela berseling panjang dan pendek dengan intervenose di antaranya. Stipe memiliki panjang 1,5-4 cm, diameter 3-5 mm, padat, berwarna putih-krem, dan tidak ada annulus (Gambar 4b). Jamur ini berperan sepagai saprofor atau agen bioremediasi (Falandysz et al., 2014). Edibilitas jamur ini belum diketahui dengan baik dan tidak ditemukan adanya laporan penggunaan jamur ini di Indonesia. Jamur tidak dikenal oleh masyarakat sekitar lokasi penelitian. 


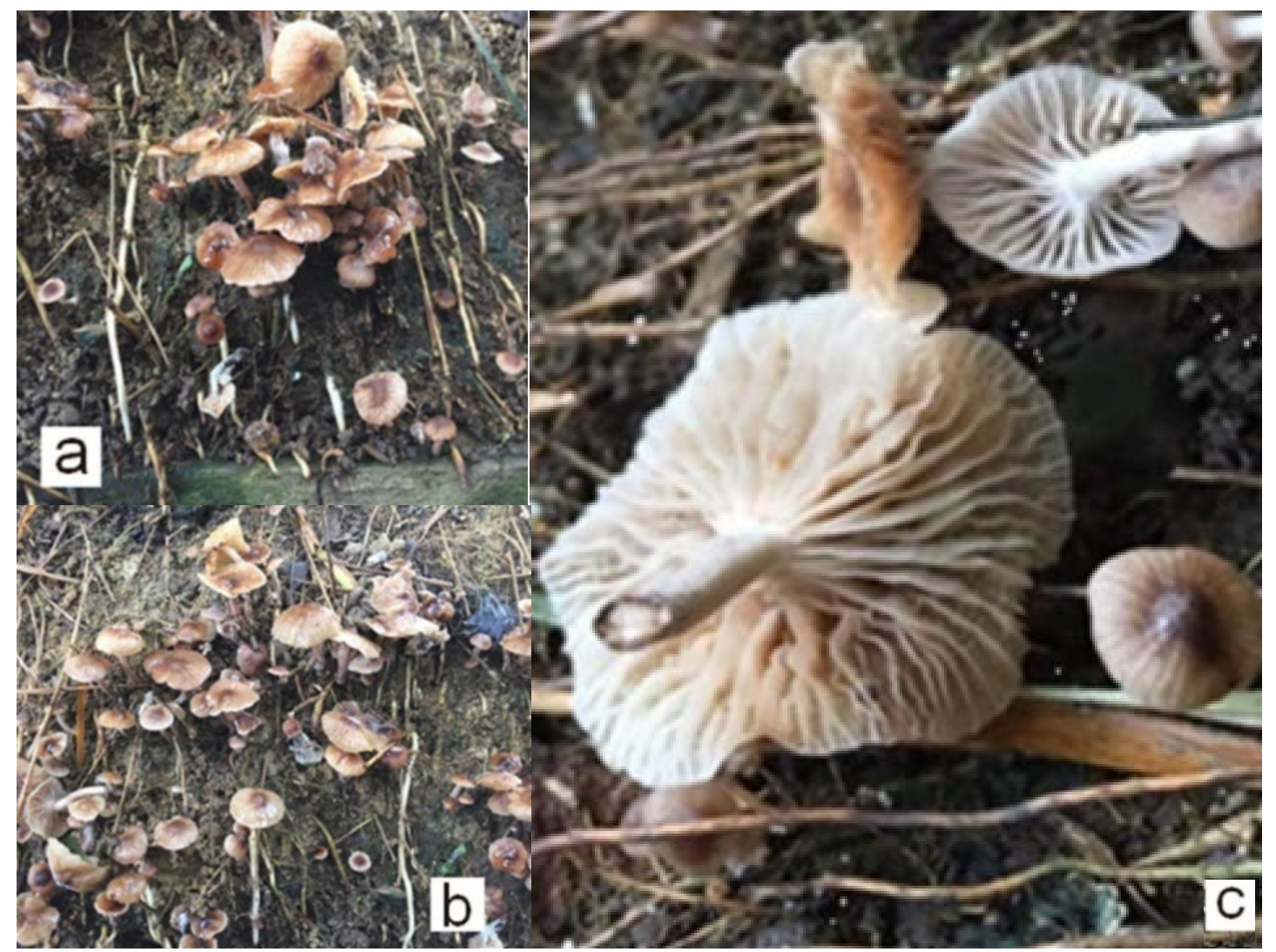

Gambar 4. Karakteristik makroskopik Gymnopus sp. a-b) Cara tumbuh tubuh buah. c) Bagian himenofor.

Figure 4. The macroscopic characteristics of Gymnopus sp. a-b) Basidiomata growth pattern. c) Hymenophore part.

\section{Coprinellus section Domestici}

Tubuh buah tumbuh berkelompok pada kayu mati. Pileus berbentuk lonceng sampai cekung (bell-shaped to convex) (Gambar 5a). Permukaan berwarna krem-coklat saat muda dan menjadi putih keabu-abuan saat dewasa, dengan piringan pusat (umbo) berwarna kecoklatan, beralur dari tepian hingga ke piringan pusat tudung, diameter 4-4,5 cm, dipenuhi butiran velum (Gambar 5c). Himenofor berlamela, mula-mula putih, menjadi kehitaman, dan meluruh saat tua (Gambar 5d). Stipe langsing, berongga, putih, panjang 5-6 cm, diameter 3-4 mm (Gambar 5b). Pertumbuhan jamur didahului dengan karpet miselia berwarna oranye terang atau ozonium (Gambar 5e-f). Genus Coprinellus secara umum bisa dimakan, tetapi bukan merupakan sumber pangan yang signifikan karena ukurannya kecil dan adanya potensi keracunan akibat senyawa coprine (Novakovic, 2016). 


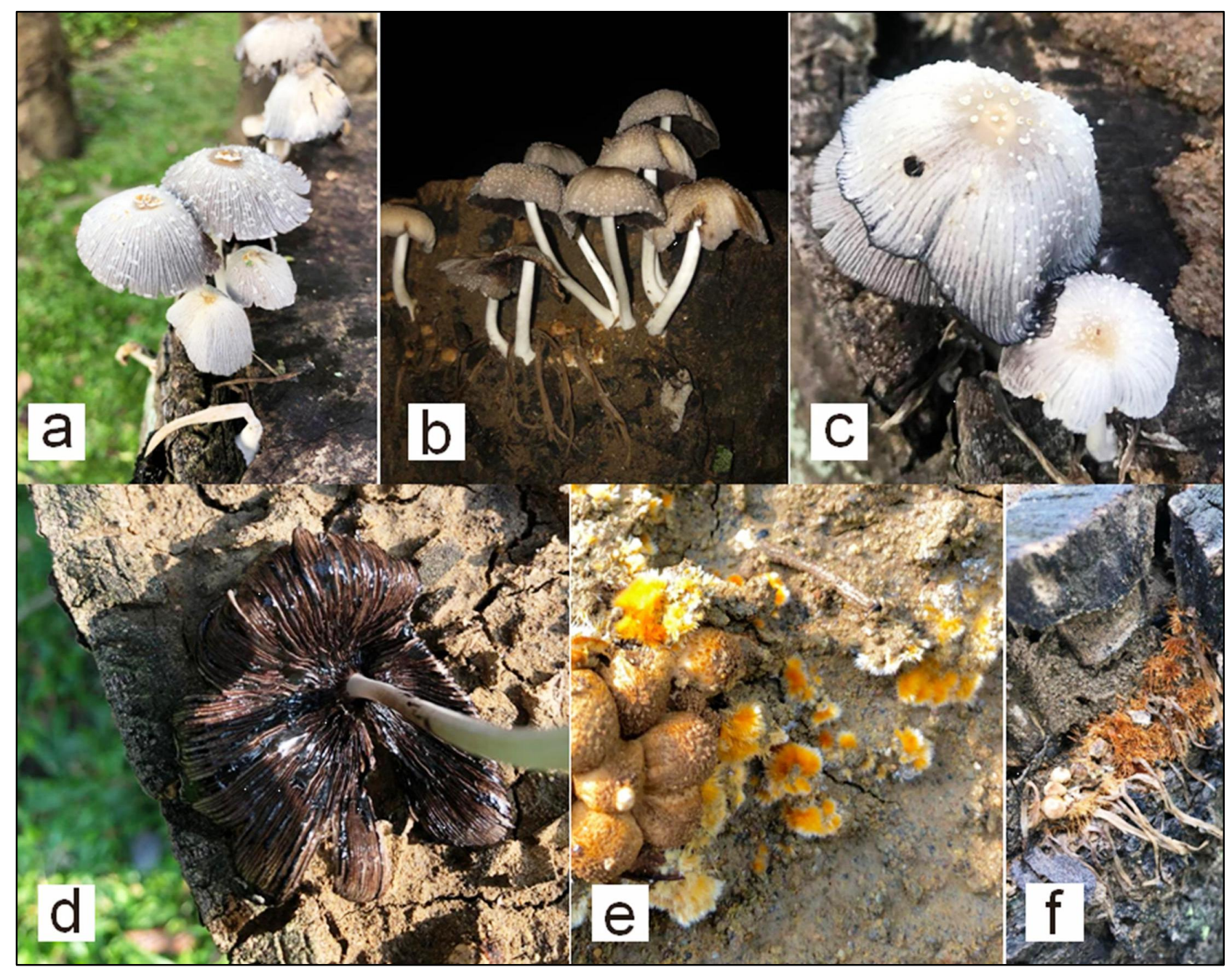

Gambar 5. Karakteristik makroskopik Coprinellus section Domestici. a) Tubuh buah tampak atas. b) Tubuh buah tampak samping.c) Tudung dengan velum dan umbo. d) Lamela yang meluruh. e) Fase primordia.

Figure 5. The macroscopic characteristics of Coprinellus section Domestici. a) The upperside of basidiomata. b) The side view of basidiomata. c) Pileus with velum and umbo. d) The delisquence of lamella. e-f) The primordia stages.

\section{Macrocybe sp.}

Jamur tumbuh di tanah penuh serasah (Gambar 6a). Pileus cembung hingga datar (convex to plane), diameter $25 \mathrm{~cm}$, tubuh buah tumbuh dari basal yang sama, berwarna coklat pucat, permukaan licin, dan mulus (Gambar 6b). Himenofor berlamela dengan warna putih/krem, dan melekat pada stipe. Tangkai memiliki diameter $3 \mathrm{~cm}$, warna krem, dengan basal stipe sangat menggembung, berdiameter $6 \mathrm{~cm}$ (Gambar 6c). Jamur Macrocybe umumnya dapat dimakan, beberapa jenis memerlukan pengolahan khusus untuk menghilangkan racun sianidanya (Pegler et al., 1998; Razaq et al., 2016). Keberadaan jamur ini juga tidak diketahui warga sekitar lokasi penelitian karena tidak ditemukan sepanjang tahun. 


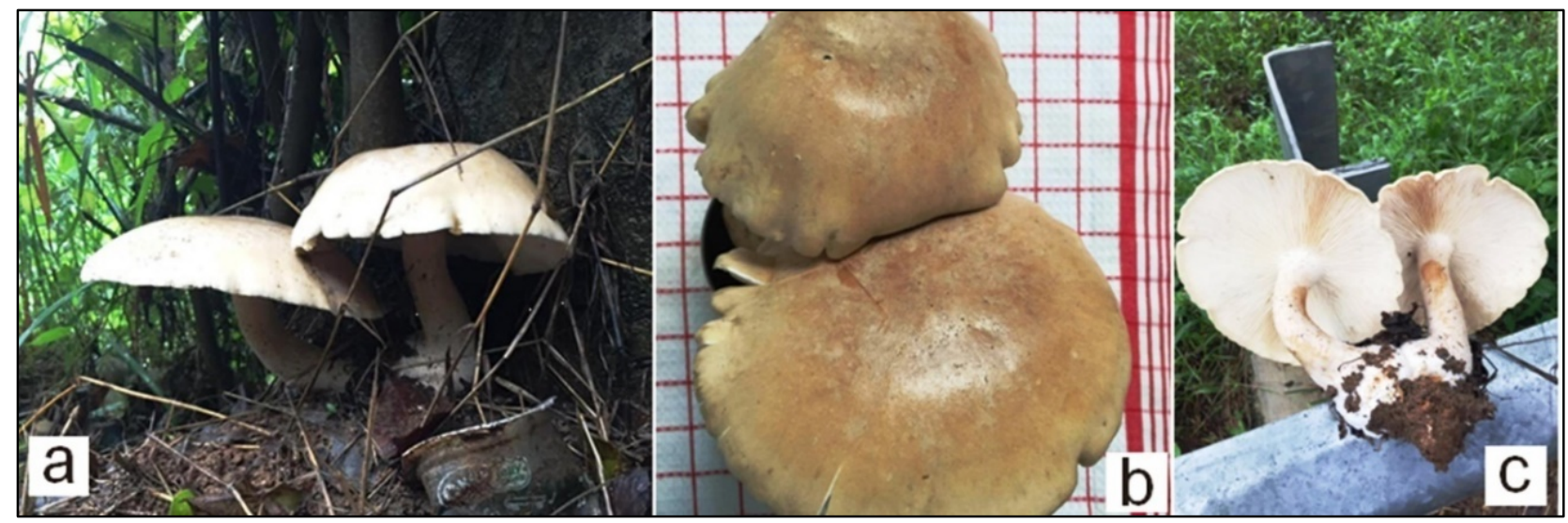

Gambar 6. Karakteristik makroskopik Macrocybe sp. a) Tempat tubuh basidiomata. b) Bagian atas tudung. c) Himenofor.

Figure 6. The macroscopic characteristics of Macrocybe sp. a) The habitat of fruiting body. b) The upperside of pileus. c) Hymenophore.

\section{Lycoperdon cf. curtisii}

Basidioma tumbuh di tanah berumput dan berkelompok dalam jarak berdekatan (Gambar 7a). Tubuh buah berbentuk bulatan putih, diameter 1,5-3 cm, dipenuhi tonjolantonjolan pendek (1-2 $\mathrm{mm})$ yang mirip duri (Gambar 7b). Saat dewasa, sebagian besar duri menghilang sehingga nampak bulatan mulus berwarna krem, dan muncul lubang (ostiole) di tengah-tengah tempat keluarnya spora (Gambar 7c). Jamur ini merupakan kelompok puffball umumnya bisa dimakan saat masih muda oleh penggiat jamur di Indonesia, ketika bagian dalamnya berwarna putih (Putra \& Hafazallah, 2020). Bal et al. (2019) melaporkan jamur ini mengandung antioksidan yang baik bagi tubuh. Jamur ini mudah dan sering dijumpai di lokasi penelitian, namun belum dimanfaatkan oleh warga lokal.

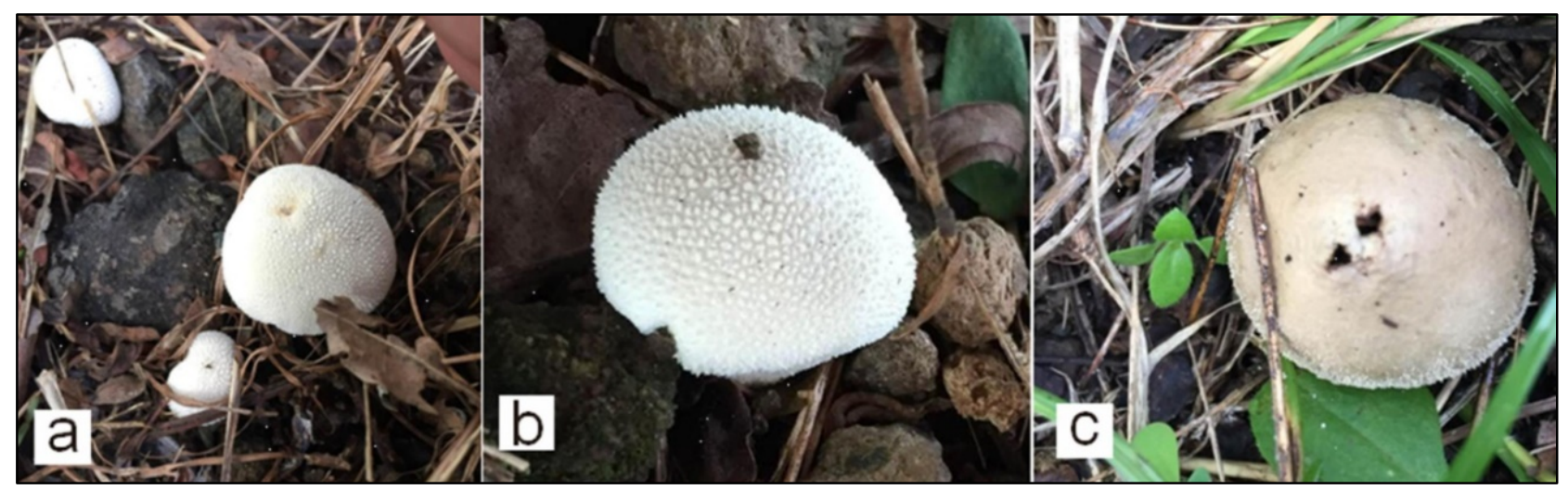

Gambar 7. Karakteristik makroskopik Lycoperdon cf. curtisii. a) Cara tumbuh. b) Duri pada permukaan basidiomata. c) Duri yang meluruh pada tubuh buah tua.

Figure 7. The macroscopic characteristics of Lycoperdon cf. curtisii. a) The growth pattern. b) The Spike on basidiomata. c) The decaying spike on basidiomata. 


\section{Ganoderma sp.}

Jamur tumbuh pada batang pohon mati dalam jarak yang cukup dekat satu sama lainnya (Gambar 8a-b). Pileus berbentuk ginjal (reniformis), cekung (concave), berukuran 25 $\mathrm{cm}$, berwarna merah kecoklatan mengkilat, tepian pileus berwarna putih saat muda, beralur dalam (sulcate) dengan pola konsentris, dengan ketebalan $6 \mathrm{~cm}$ (Gambar 8c). Tubuh buah muda memiliki lebar 1,5-2 cm (Gambar 8d). Himenofor berpori, pori berbentuk bulat, berwarna puth (Gambar 8e), rapat, undetachable, dan menempel pada stipe secara lateral. Panjang tangkai $8 \mathrm{~cm}$ dan berwarna coklat kemarahan. Secara keseluruhan, tekstur jamur keras dan berbau kayu. Ganoderma yang ditelaah pada penelitian ini termasuk dalam lingzhi/reishi complex. Beberapa laporan sebelumnya menyebutkan bahwa jamur ini memiliki aktivitas antimikroba (Tamilselvan \& Rajesh, 2019) dan juga dimanfaatkan untuk pengobatan kanker (Sohretoglu \& Huang, 2018). Jamur ini mudah dijumpai dan bertahan relatif lama di daerah penelitian. Namun, pemanfaatannya tidak dikenal oleh warga di sekitar lokasi penelitian.

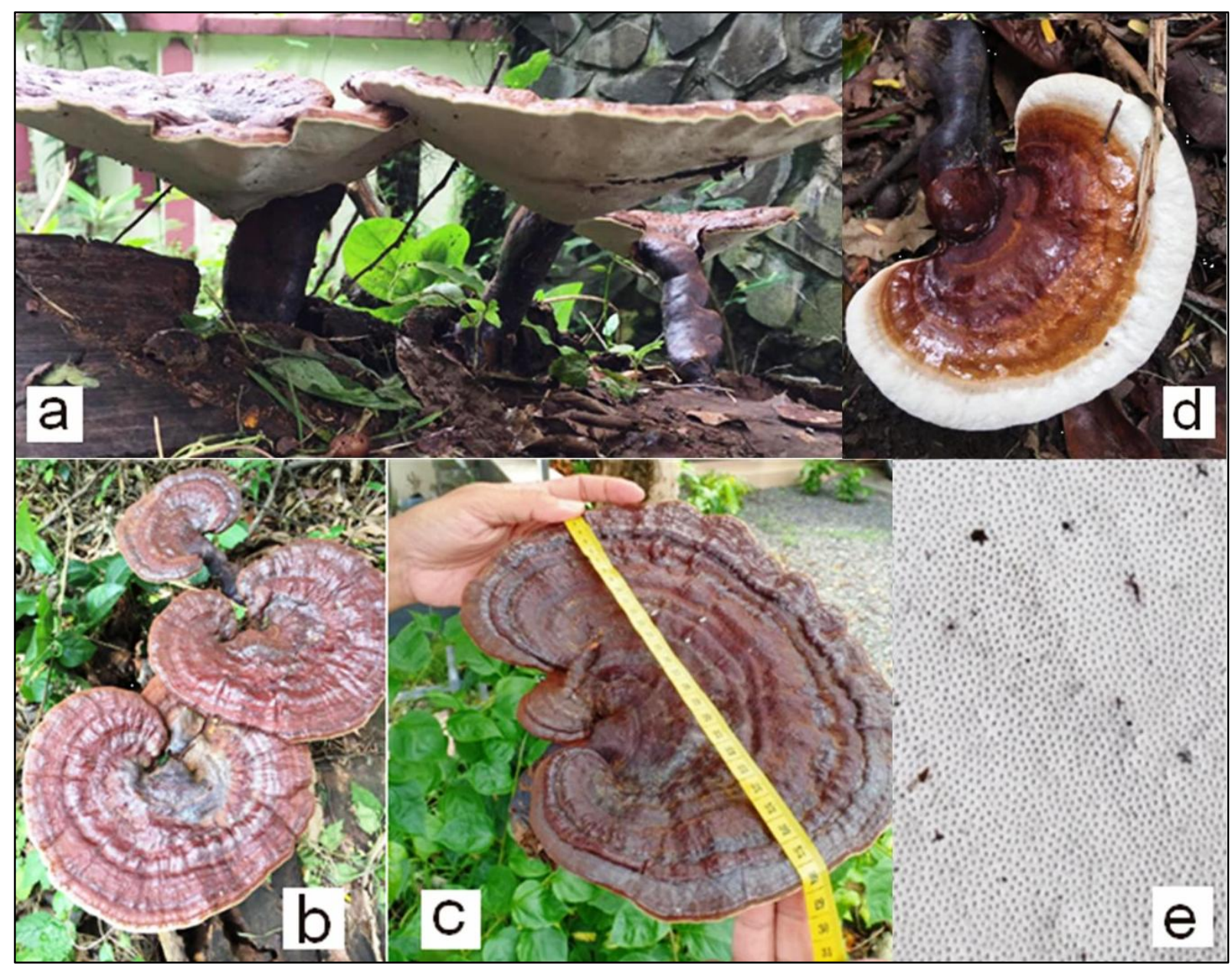

Gambar 8. Karakteristik makroskopik Ganoderma sp. a) Tubuh buah dengan tangkai. b-c) Tubuh buah dewasa tampak atas. d) Tubuh buah muda. e) Himenofor.

Figure 8. The macroscopic characteristics of Ganoderma sp. a) Basidiomata with stipe. b-c) Theupperside view of mature fruiting body. d) The young basidiomata. e) Hymenophore. 


\section{Lentinus cf. sajor-caju}

Tubuh buah tumbuh di pohon mati dan berkelompok (Gambar 9a). Pileus memiliki diameter 10-12 cm, warna coklat muda, tekstur alot, dengan cekungan di tengah berwarna lebih gelap, sedikit bersisik, berbentuk corong datar, margin pileus sedikit melengkung ke arah dalam (Gambar 9b). Himenofor berlamela dengan pelekatan decurrent pada stipe, dengan warna putih-krem. Stipe dengan posisi sentral, panjang 3-4 cm, diameter 5-8 $\mathrm{mm}$, warna $\mathrm{krem} /$ coklat muda, solid, memilki annulus/cincin (Gambar 9c). Lentinus dikenal sebagai jamur lot di Pulau Jawa karena teksturnya yang alot (keras) (Putra \& Hafazallah 2020). Jamur ini merupakan salah satu jamur pangan liar (Singdevsachan et al., 2013; Putra \& Hafazallah 2020). Tekstur tubuh buah jamur saat tua tergolong liat, sedangkan tekstur jamur muda lebih mudah dikunyah Putra \& Hafazallah 2020). Warga sekitar tidak memanfaatkan jamur ini walaupun relatif mudah dijumpai dalam kurun waktu penelitian ini.

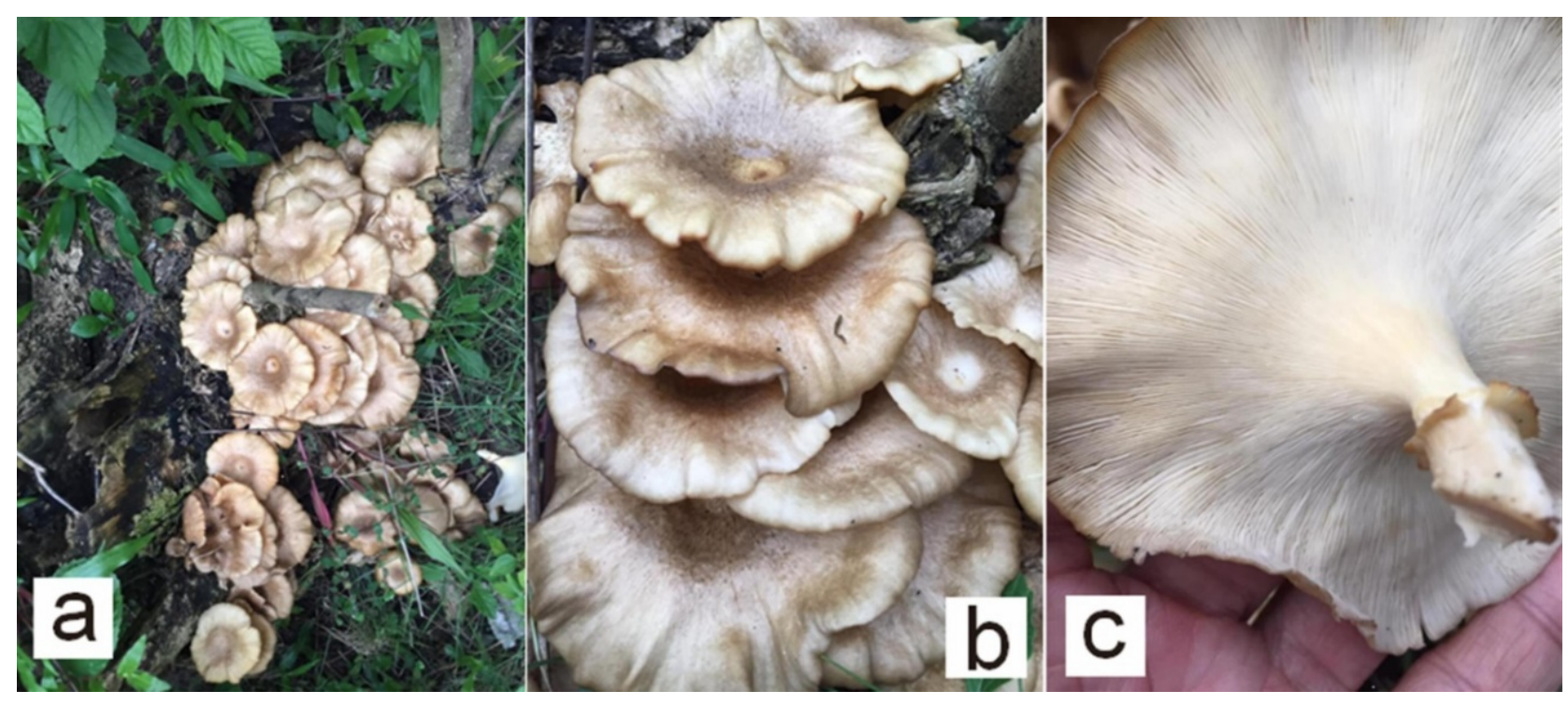

Gambar 9. Karakteristik makroskopik Lentinus cf. sajor-caju. a) Cara tumbuh. b) Tubuh buah tampak atas. c) Tudung tampak bawah.

Figure 9. The macroscopic characteristics of Lentinus cf. sajor-caju. a) Growth pattern. b)The upperside of basidiomata. c) The underside of pileus.

\section{Mutinus cf. elegans}

Basidioma tumbuh di tanah penuh serasah daun bambu, berkelompok atau soliter (Gambar 10d). Primodia jamur berbentuk oval mirip telur yang berakar (rhizomorph), dengan panjang 2-3 cm. Saat dibelah, terlihat calon tubuh buah yang terbungkus lapisan gelatinous (Gambar 10a-b). Jamur dewasa berbentuk seperti pasak berongga, meruncing (spike), panjang 7-16 $\mathrm{cm}$, bagian dasar memiliki cangkang (volva), berlobang-lobang kecil seperti spons, dengan warna putih dan ujung runcingnya berwarna merah (Gambar 10c, 10e). Terdapat lapisan cairan kental dengan warna abu-abu-kehijauan yang menyelimuti sebagian ujung runcingnya, berbau busuk, menyengat, dan menarik serangga seperti lalat. Fase telur dari jamur ini diduga bisa dimakan, namun tidak disarankan karena adanya berbagai laporan yang kontradiktif mengenai edibilitasnya (Arora, 1986). 


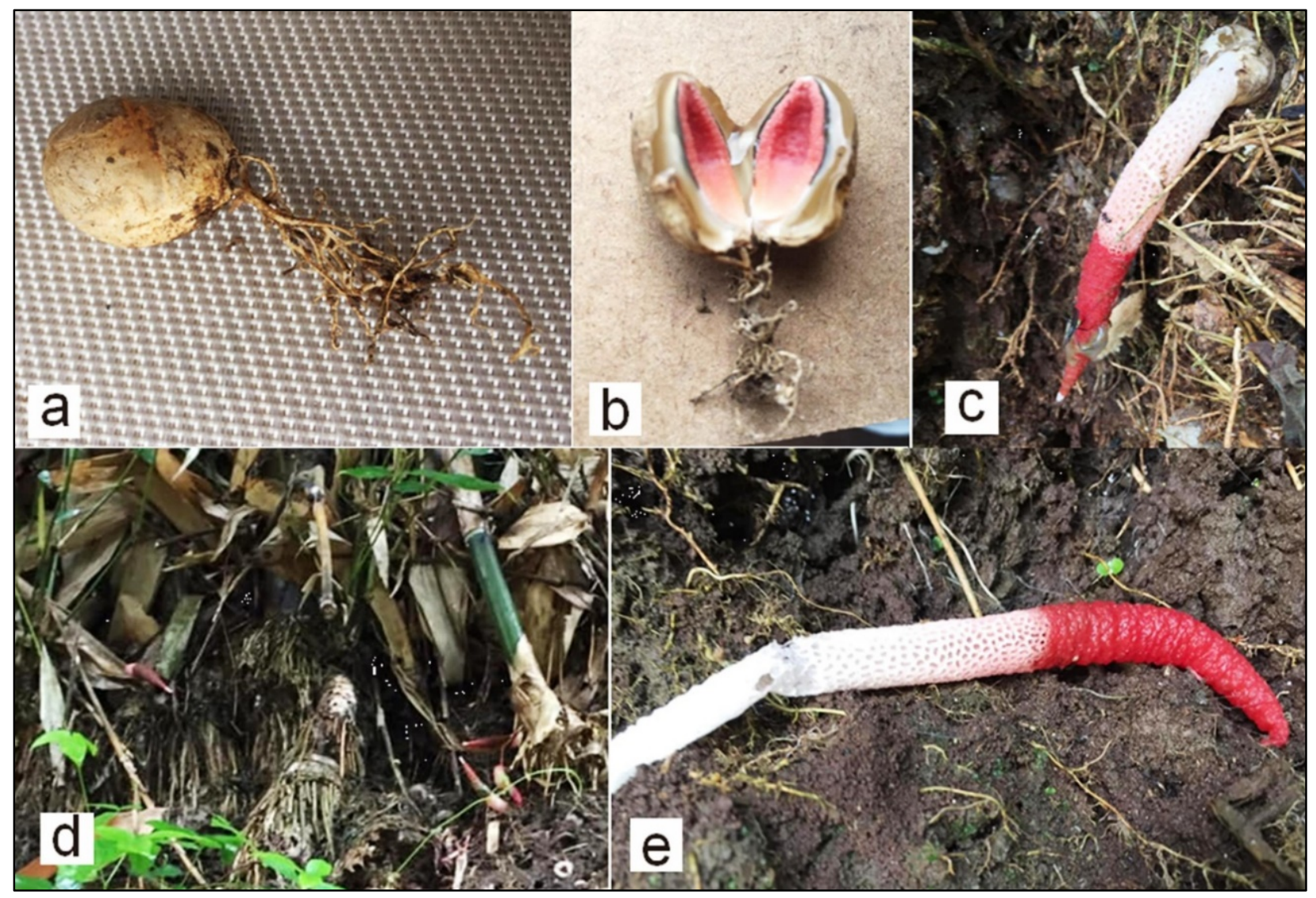

Gambar 10. Karakteristik makroskopik Mutinus cf. elegans. a) Fase telur. b) Bagian dalam telur. c) Reseptakel yang tumbuh dari telur. d) Habitat tumbuh. e) Bagian ujung tangkai yang berwarna merah.

Figure 10. The macroscopic characteristics of Mutinus cf. elegans. a) Egg phase. b)Egg interior. c) Reseptaclearising from egg. d) Habitat. e) Red part of reseptacle.

\section{Geastrum sp.}

Basidioma tumbuh di tanah berhumus (Gambar 11a). Jamur ini dikenal sebagai earthstar atau bintang bumi. Lapisan luar (peridium) terbelah membentuk bintang dengan lima lengan, peridium berwarna krem pada bagian luarnya, dan kemerahan di bagian dalam. Kantong spora berbentuk bulat di tengah peridium yang terbuka, diameter $1-1.5 \mathrm{~cm}$, dan berlubang di bagian tengah (Gambar 11b).
Bagian basal melekat pada struktur semacam akar (rhizomorph) (Gambar 11c). Gaestrum dilaporkan tumbuh sebagai ektomikoriza pada akar pepohonan (Karun \& Sridhar, 2014) dan juga saprofit pada tanah berhumus (Verma et al., 2018). Geastrum yang ditemukan pada penelitian ini tumbuh di tanah basah berhumus di sekitar sawah. Keberadaan jamur ini tidak dikenal warga sekitar karena bentuknya yang kecil dan letak yang tersembunyi dalam tanah. 


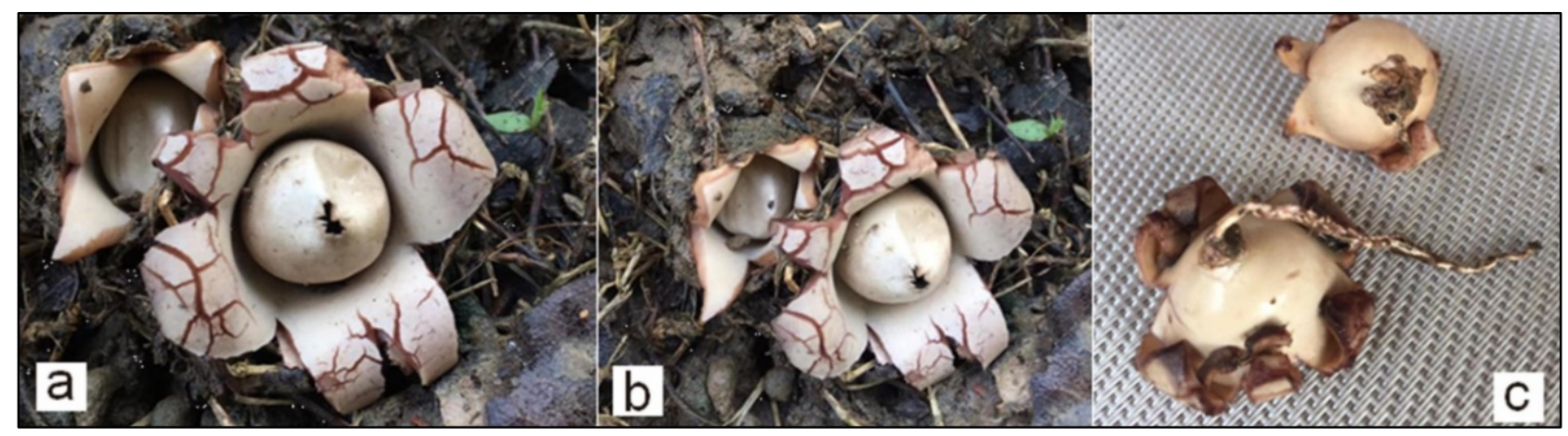

Gambar 11. Karakteristik makroskopik Geastrum sp. a-b) Tubuh buah tampak atas. c) Tubuh buah tampak bawah.

Figure 11. The macroscopic characteristics of Geastrum sp. a-b) The upperside of basidiomata. c) The underside of basidiomata.

\section{KESIMPULAN}

Sejumlah 10 spesies jamur yang terbagi dalam 6 Ordo dan 9 Family berhasil dilaporkan pada penelitian ini. Spesies-spesies tersebut adalah: Auricularia cf. nigricans, Tremella cf. fuciformis, Gymnopus sp., Coprinellus sect. Domestici, Macrocybe sp., Lycoperdon cf. curtisii, Ganoderma sp., Lentinus cf. sajor-caju, Mutinus cf. elegans, dan Geastrum sp. Secara umum, jamur yang dijumpai memiliki peranan sebagai dekomposer. Beberapa jamur diketahui memilki potensi sebagai bahan pangan (Auricularia cf. nigricans, Coprinellus sect. Domestici, Macrocybe sp., Lycoperdon cf. curtisii, Lentinus cf. sajor-caju) dan obat (Auricularia cf. nigricans, Ganoderma sp., Tremella $\mathrm{cf}$. fuciformis).

Hasil penelitian ini dapat dimanfaatkan oleh masyarakat Kota Semarang sebagai media diseminasi ragam dan manfaat jamur di sekitar wilayah pemukiman. Selain itu, informasi yang dikoleksi dapat dimanfaatkan sebagai bahan pengajaran oleh pelajar, guru, dosen, mahasiswa, peneliti dan berbagai Institusi di sekitar lokasi penelitian.

\section{UCAPAN TERIMA KASIH}

Penulis mengucapkan terimakasih kepada Departemen Biologi Institut Pertanian 86
Bogor, Komunitas Pemburu Jamur Indonesia, dan Masyarakat Kecamatan Gunungpati, Kota Semarang, Jawa Tengah yang telah membantu penelitian ini.

\section{DAFTAR PUSTAKA}

Arora, D. (1986). Mushrooms Demystified. USA: Teen Speed Press.

Badalyan, S. M. (2020). Medicinal Coprinoid Mushrooms (Agaricomycetes) Distributed in Armenia (Review). International Journal of Medicinal Mushrooms, 22(3), 257-267. doi:10.1615/intjmedmushrooms.202003 3981.

Bal, C., Akgül, H., \& Sevindik, M. (2019). The Antioxidant potential of ethanolic extract of edible mushroom Lycoperdon molle Pers. (Agaricomycetes). Eurasian Journal of Forest Science, 7(3), 277-283. doi:10.31195/ejejfs.591432.

Bandara, A., Rapior, S., Mortimer, P., Kakumyan, P., Hyde, K.D., \& Xu, J. (2019). A review of the polysaccharide, protein and selected nutrient content of Auricularia, and their potential pharmacological value. Mycosphere , 10(1). 579-607. 
doi:10.5943/mycosphere/10/1/10.

Mapoung, S., Umsumarng, S., Semmarath, W., Arjsri, P., Thippraphan, P., Yodkeeree, S., \& Limtrakul (Dejkriengkraikul), P. (2021). Skin Wound-Healing Potential of Polysaccharides from Medicinal Mushroom Auricularia auricula-judae (Bull.). Journal of Fungi, 7(4), 247. doi:10.3390/jof7040247.

Dewi, N. K., \& Rudiarto, I. (2013). Identifikasi Alih Fungsi Lahan Pertanian dan Kondisi Sosial

Ekonomi Masyarakat Daerah Pinggiran di Kecamatan Gunungpati Kota Semarang. Jurnal Wilayah dan Lingkungan, $\quad 1(2), \quad$ 175-188. doi:10.14710/jwl.1.2.175-188.

Desjardin, D. E., Wood, M., \& Stevens, F. A. (2014). California mushrooms: The comprehensive identification guide. Portland:Timber Press.

Falandysz, J., Dryżałowska, A., Saba, M., Wang, J., \& Zhang, D. (2014). Mercury in the fairy-ring of Gymnopus erythropus (Pers.) and Marasmius dryophilus (Bull.) P. Karst. mushrooms from the Gongga Mountain, Eastern Tibetan Plateau. Ecotoxicology and Environmental Safety, 104 , $18-22$. doi:10.1016/j.ecoenv.2014.02.012.

Gregori, A., \& Pohleven, F. (2014). Cultivation of three medicinal mushroom species on olive oil press cakes containing substrates. Acta Agriculturae Slovenica, 103(1), 49-54. doi:10.14720/aas.2014.103.1.05.

Li, H, Tian, Y, Menolli, N, et al. (2021). Reviewing the world's edible mushroom species: A new evidence-based classification system. Compr Rev Food Sci

Food
Saf. 20: 1982-2014. https://doi.org/10 .1111/1541-4337.12708.

Karun, N. C., \& Sridhar, K. R. (2014). Geasters in the Western Ghats and west coast of India. Acta Mycologica, 1(1), 207-219. doi:10.5586/am.2014.023.

Kecamatan

Gunungpati. https://kecgunungpati.semarangkota.go.id /profil-kecamatan. [Diakses pada 25 Juli 2021].

Kuo, M. (2008). Tremella fuciformis. Diakses dari MushroomExpert.Com. Website: http://www.mushroomexpert.com/treme lla_fuciformis.html.

Mueller, G. M., Schmit, J. P., Leacock, P. R., Buyck, B., Cifuentes, J., Desjardin, D. E.,\& Wu, Q. (2006). Global diversity and distribution of macrofungi. Biodiversity and Conservation, 16(1), 37-48. doi:10.1007/s10531-006-91088.

Novakovic, A., Karaman, M., Kaisarevic, S., Belovic, M., Radusin, T., Beribaka, M., \& Ilic, N. (2016). Coprinellus disseminatus (Pers.) J.E. Lange 1938: In vitro antioxidant and antiproliferative effects. Food and Feed Research, 43(2), 93-101. doi:10.5937/ffr1602093n.

[LIPI] Lembaga Ilmu Pengetahuan Indonesia. (2019). Status keanekaragaman hayati Indonesia: kekayaan jenis tumbuhan dan jamur Indonesia. Retnowati A, Rugayah, Rahajoe JS, Arifiani D. editor. Jakarta (ID): LIPI Press.

Pegler, D.N.; Lodge, D.J.; \& Nakasone, K.K.(1998). The Pantropical Genus Macrocybe Gen. nov. Mycologia, 90 (3), 494-504. doi:10.2307/3761408.

Putra, I.P., Mardiyah, E., Amalia, N.S., \& Mountara, A. (2017). Ragam jamur asal serasah dan tanah di Taman Nasional Ujung Kulon Indonesia. Jurnal 
Sumberdaya Hayati, 3(1), 1-7. doi: https://doi.org/10.29244/jsdh.3.1.17

Putra, I.P., Sitompul, R., \& Chalisya, N. (2018). Ragam Dan Potensi Jamur Makro Asal Taman Wisata Mekarsari Jawa Barat. Al-Kauniyah: Jurnal Biologi, 11(2), 133-150.

http://dx.doi.org/10.15408/kauniyah.v1 1 i2.6729.

Putra, I.P., Nasrullah, M.A., \& Dinindaputri, T.A. (2019). Study on Diversity and Potency of Some Macro Mushroom at Gunung Gede Pangrango National Park. Buletin Plasma Nutfah, 25(2), 1-14. http://dx.doi.org/10.21082/blpn.v25n2.2 019.p1-14.

Putra, I.P., \& Hafazallah, K. (2020). Catatan Komunitas PemburuJamur Indonesia : Kolaborasi Lintas Profesi dan Generasi Mengenai Etnomikologi Jamur-Jamur Indonesia. Sukabumi : Haura Publishing.

Putra, I.P. \& Astuti, M. (2021). Catatan Beberapa Jamur Liar yang Tumbuh di Sekitar Pemukiman Penduduk. Quagga Jurnal Pendidikan dan Biologi, 13(1): 48-59. doi: https://doi.org/10.25134/quagga.v $13 \mathrm{i} 1.3617$

Putra, I.P. (2021). Panduan karakterisasi jamur makroskopik di Indonesia: Bagian 1 Deskripsi ciri makroskopis. Jurnal Penelitian Kehutanan Wallacea, 10(1), 25-37.

http://dx.doi.org/10.18330/jwallacea.2 021.vol10iss1pp25-37.

Prayudi, D. P., Kurniawati, J., Mutiarani, Y. P., Salim, I., \& Aminatun, T. (2019). Considering Sampling Methods for Macrofungi Exploration in Turgo Tropical Forest Ecosystem. Journal of
Tropical Biodiversity and Biotechnology, 4(1), 1-10. doi:10.22146/jtbb.38381.

Razaq, A. Nawaz, R. \& Khalid, A.N. (2016). An Asian edible mushroom, Macrocybe gigantea: Its distribution and ITSrDNA based phylogeny. Mycosphere, 7 , 525-530. doi:10.5943/mycosphere/7/4/11.

Rokuya, I., Yoshio, O., \& Tsugia, H. (2011). Fungi of Japan. Japan: Yama-Kei Publishers.

Shahrajabian, M. Hesam, Sun, Wenli., Shen, Hong, \& Cheng, Qi. (2020). Chemical compounds and health benefits of Tremella, a valued mushroom as both cuisine and medicine in ancient China and modern era. Amazonian Journal of Plant Research. 4(3), 692-697. doi:10.26545/ajpr.2020.b00077x

Singdevsachan, S.K., Patra, J.K. \& Thatoi, H. (2013). Nutritional and bioactive potential of two

wild edible mushrooms (Lentinus sajorcaju and Lentinus torulosus) from Similipal Biosphere Reserve, India. Food Science and Biotechnology, 22(1), 137-145. doi:10.1007/s10068-0130019-7.

Sohretoglu, D., \& Huang, S. (2018). Ganoderma lucidum Polysaccharides as An Anti-cancer Agent. Anti-Cancer Agents in Medicinal Chemistry, 18(5), 667-674.

doi:10.2174/1871520617666171113121 246.

Tamilselvan, N., \& Rajesh, K. (2019). Antimicrobial Efficacy of Medicinal Mushroom Ganoderma Lucidum. International Journal of Trend in Scientific Research and Development, 3(3)),

1798-1800. 
doi:10.31142/ijtsrd23522.

Tampubolon, S. D. B. M., Utomob, B., \& Yunasfi. (2013). Keanekaragaman JamurMakroskopis di Hutan Pendidikan Universitas Sumatera Utara Desa Tongkoh kabupaten Sumatera Utara. Peronema Forestry Science Journal,
2(1), 176-182.

Verma, R. K., Pandro, V., Raj, D., \& Patel, D. (2018). Diversity of macro-fungi in Central India-XVII: Geastrum fimbriatum and Geastrum triplex. Van Sangyan, 5(10), 1-11. 